\title{
Learning Quality of State Elementary School 4 Makarti Jaya Under the Leadership of Visionary School
}

\author{
Soliyah $^{1 *)}$, Edi Harapan ${ }^{2}$, Tahrun $^{2}$ \\ ${ }^{1}$ SD Negeri 4 Makarti Jaya \\ ${ }^{2}$ Universitas PGRI Palembang \\ *Corresponding author.Email:solia4081@gmail.com
}

\begin{abstract}
The results of this study indicate that: (1) The learning quality of SD Negeri 4 Makarti Jaya under the leadership of the visionary principal in terms of the quality of teaching teachers can be said to be good. In the learning process delivered by educators who helped to improve the quality of learning of students at SD Negeri 4 Makarti Jaya, they had planned the lesson plan in advance according to the direction of the school principal, carried out learning, followed up, and provided guidance and counseling; (2) the principal has made every effort to improve the quality of learning at SD Negeri 4 Makarti Jaya, where the library space is improved and the number of existing book collections is made, learning resource facilities are used as supporting media to improve the quality of learning, such as Indonesian Language Kits, KitsScience, Non-science Kit, Math Kit, art equipment, sports equipment were good; (3) Constraints faced by the principal's visionary leadership toimprove the quality of learning in SD Negeri 4 Makart Jaya, where there are still teachers who help in the learning process who are not linear with the material being taught. Besides that, especially honorarium teachers are still often absent. The other problem is that there is still a lack of existing infrastructure such as books in the library, teacher's handbooks, and teaching aids.
\end{abstract}

Keywords: Quality of Learning, Principal, Visionary School

\section{INTRODUCTION}

The principal is a leader in the school who has the authority to make innovations, breakthroughs, and new breakthroughs in realizing the progress of the school he leads. The principal is mandated to make changes. This mandate is often called political power that neither teachers nor employees have. The visionary leadership of the principal is expected to realize school progress. visionary leadership is a leader who has a clear future direction and form which is a picture of an agreed future with a sense of togetherness and high commitment to make it happen. Meanwhile, according to Triana [1], visionary leadership is a leader's ability to create, formulate, communicate, socialize, transform, implement thoughts, and the results of social interaction of members of the organization and stakeholders as the ideals of the organization in the future that must be realized through all personalities. From these two opinions contain the understanding that visionary leadership must facilitate strengthening of thinking, insight, action and orientation towards the future.

To improve the quality of education, visionary principals can carry out their roles, including direction determinants, designers, change agents, trainers, problem solvers, and motivators. There are many ways that can be done to implement this role, namely: (1) by having realistic and measurable targets. The principal must make a clear work program by analyzing the strengths, weaknesses, obstacles, and existing resources and communicating them with the school committee, stakeholders and all related parties, (2) by improving the quality of teaching staff (teachers) and education personnel (employees ). To create superior teachers and employees, it can be done by means of guidance. Internal coaching can be done in several ways, namely continuous coaching and motivation accompanied by exemplary, building teacher and employee loyalty, giving rewards and punishment, optimal empowerment accompanied by continuous control. Coaching can also involve external (external) parties from the education office and other institutions related to the purpose of coaching, (3) by implementing a superior service system. Excellent services for students can be done in several ways including schools carrying out interesting, creative, innovative, fun teaching and learning activities according to the curriculum through planning, implementing, evaluating, assessing, enriching / 
remedial processes that are programmed, orderly, scheduled, and controlled, (4) by having clear, complete and transparent administration. All forms of school administration, especially the administration of eight educational standards, are made continuously and continuously. Clear, complete, and transparent administration is not only the responsibility of those responsible for the eight education standards but all teachers and employees [2].

Based on the researcher's interview with the Principal of SDN 4 Makarti Jaya, it was stated that as the school leader, he always refers to the vision, mission and goals to be achieved at SDN 4 Makarti Jaya. In managing the school, he always tries to improve the quality of teachers in managing the class. However, the obstacles faced are the facilities and infrastructure at SDN 4 Makarti Jaya are still inadequate, such as there are not many books in the library, only 1 teacher's handbook, should be at least 2 or 3 handbooks so that they can be more meaningful in when the teacher delivers the learning process. Besides that, the media for teaching aids as a supporting learning resource are also inadequate, given the very rapid development of technology and the need for reliable and professional teachers.Learning Quality SD Negeri 4 Makarti Jaya Under the Leadership of the Visionary School Principal.

\section{METHODS}

The location of the research was at SD Negeri 4 Makarti Jaya. Banyuasin Regency, 2020/2021 school year. The research period was conducted for 3 (three) months, namely September 2020 - November 2020.In this research is a qualitative descriptive research method. According to Prastowo [3], the descriptive method is a method used to examine the status of a group of people, an object, a set of conditions, a system of thought, or a class of events in the present. According to Sukamadinata, et al [4], qualitative research is research to describe and analyze phenomena, events, social activities, beliefs, perceptions, thoughts individually or in groups. Arikunto [5] states "the research method is the method used by researchers in collecting research datastates that "a method is defined as a method used to achieve predetermined goals.

\section{RESULTS AND DISCUSSION}

Based on research data regarding the quality of learning SD Negeri 4 Makarti Jaya under the leadership of the visionary principal, where the data is obtained from: (1) observation, (2) interviews, (3) documentation. Observational research data explains the quality of learning SD Negeri 4 Makarti Jaya in terms of the quality of teaching teachers, the quality of learning in terms of infrastructure in SD Negeri 4 Makarti Jaya, the obstacles faced.
The visionary principal as the leader of the educational institution at SDN 4 Makarti Jaya, Banyuasin Regency has carried out scheduled supervision, controlled school staff and residents to always comply with school rules and guide school staff and residents to always carry out their duties with full responsibility. The visionary principal as the leader of the educational institution at SDN 4 Makarti Jaya, Banyuasin Regency, the school always conducts periodic evaluations both quarterly, per semester and during the School Final Examination and the Principal tries to solve problems such as there are students who get grades in under the KKM, and these students are given remedials so that the scores obtained reach the specified KKM and provide additional lessons for class VI students so that graduation achieved from learning outcomes and learning achievement can be improved. This is supported by Sallis [6] that a visionary leader will not leave the discussion until everything is clear. After reaching an agreement, we must know clearly what next steps should be taken. Whatever we say must be clear and we must be able to stick with the values we offer.

Management in general is an activity process that starts from planning, organizing, implementing, leading and controlling the efforts of members of the organization and utilizing all organizational resources in order to achieve predetermined goals. The principal is the person responsible for managing the organization as well as supervising. In fact, he acts as a supervisor, but in a modern educational organizational system, special supervisors are needed who are more independent and can increase objectivity in coaching and carrying out their duties. The school principal must be able to carry out various supervision and controls to improve the performance of educational personnel. Supervision and control is a control so that educational activities in schools are directed at predetermined goals [7].

Hidayah [8] states that the success of the school in improving the quality of education, good academic and non-academic quality very much depends on the principal for lead by vision. Its role as visionary leaders can improve quality school, one of which is by increasing teacher quality. However, if the principal don't have a vision for the future it will inhibits the development of teacher creativity. In the teaching process, teachers only teach according to their duties only in teaching, they don't have a target which is clear as a result of the process the learning.

Besides that, the visionary leadership of the principal has to address some sub variables as stated by Komariah and Triatna [9] including: the ability to determine the direction of the organization; understanding the wishes of the community or consumers; be influential in activities and be a guide; and be able to anticipate 
Eventually, the researcher also found the problems in field. The obstacles encountered by Principal's Visionary Leadership in Improve the Quality of Learning in SD Negeri 4 Makarti Jaya there are still teachers who help in the learning process who are not linear with the material. It is one of the essential problems that become the principal's responsibility. In line with this problem, Hanim, et [7] al suggested that the principal has to solve the problem by recruiting some other teachers as well as providing additional works as the administrative duties. Recruiting and training teachers can be done in a number of ways. In the best-case situation, there are advantages to employing fully trained teachers who can begin their careers at a higher degree of effectiveness [10].

\section{CONCLUSION}

The learning quality of SD Negeri 4 Makarti Jaya under the leadership of the visionary principal in terms of the quality of teaching teachers can be said to be good. In the learning process delivered by educators who help to improve the quality of learning of students at SD Negeri 4 Makarti Jaya, they have planned the lesson plans in advance according to the direction of the school principal, the teacher is able to carry out learning according to the curriculum design that was made jointly and is in accordance with the needs of students. Teachers are able to evaluate the results of the learning process that has been implemented, both evaluations carried out every mid-semester, per semester as well as evaluations carried out at the end of each year and preparation for student graduation. Teachers are able to provide guidance and counseling to students, especially for students who have difficulty learning by providing remedials and enrichment. In addition, in improving the quality of learning, the teacher delivers learning materials using handbooks, teaching aids, subject kits that are tailored to the learning materials in the designed curriculum.

Visionary leadership of the Principal in improving the quality of learning in terms of infrastructure at SD Negeri 4 Makarti Jaya, it is known that the principal has made every effort to improve the quality of learning at SD Negeri 4 Makarti Jaya, where library space improvements are carried out and increase the number of existing book collections, learning resource facilities as a supporting medium to improve the quality of learning, such as the Indonesian Language Kit, Science Kit, Social Studies Kit, Mathematics Kit is equipped, art tools can be said to be good, sports equipment can be said to be good. Constraints faced by the principal's visionary leadership inimprove the quality of learning in SD Negeri 4 Makarti Jaya, where there are still teachers who help in the learning process who are not linear with the material being taught. Besides that, especially honorarium teachers are still often absent. Besides that, there are still lack of existing infrastructure such as books in the library, teacher's handbooks, teaching aids, even though a proposal has been submitted to the Banyuasin Regency Education and Culture Office to complete these facilities, but the problem is that sometimes the submission process takes a long time.

\section{REFERENCES}

[1] Triana. (2015). Movement to Organize the Quality of Education: Theory and Application. Yogyakarta: Ar-Ruz Media.

[2] Mulyasa, E. (2011). Menjadi Kepala Sekolah Profesional. Bandung. Remaja Rosdakarya.

[3] Prastowo, A. (2011). Qualitative Research: Learning Design Techniques. Jogjakarta: Diva Press.

[4] Sukmadinata, N. S. (2011). Educational Research Methods. Bandung: Remaja Rosdakarya.

[5] Arikunto, S. (2010). Research Procedure A Practice Approach. Revised Edition. Jakarta: Rineka Cipta.

[6] Sallis, E. (2016). Education Quality Management, translation Fahrurrozi. Jakarta: Rajawali Press.

[7] Hanim, et al. (2020). Kebijakan Kepemimpinan Kepala Sekolah dalam Meningkatkan Efektivitas Kinerja Guru. Jurnal Manajemen Pendidikan. 2 (1). $43-60$.

[8] Hidayah, N. (2012). Kepemimpinan Visioner dalam Meningkatkan Mutu Pendidikan. Jakarta: Bumi Aksara

[9] Komariah, A., \& Triatna, C. T. (2010). Visionary Leadership Menuju Sekolah Efektif. Jakarta: Bumi Aksara

[10] Darling-Hammond, L., Holtzman, D. J., Gatlin, S. J., \& Heilig, J. V. (2005). Does teacher preparation matter? Evidence about teacher certification, Teach for America, and teacher effectiveness. Education policy analysis archive, 13 (42). 